medRxiv preprint doi: https://doi.org/10.1101/2022.01.10.22268896; this version posted January 10, 2022. The copyright holder for this preprint (which was not certified by peer review) is the author/funder, who has granted medRxiv a license to display the preprint in

All rights reserved. No reuse allowed without permission.

\title{
Protective effect of a first SARS-CoV-2 infection from reinfection: a matched retrospective cohort study using PCR testing data in England
}

Joanne Lacy ${ }^{1}$, Anna Mensah ${ }^{1}$, Ruth Simmons ${ }^{1}$, Nick Andrews ${ }^{1}$, M. Ruby Siddiqui ${ }^{1}$, Antoaneta Bukasa $^{1}$, Shennae O'Boyle ${ }^{1}$, Helen Campbell1, Kevin Brown ${ }^{1}$

1 Immunisation and Vaccine Preventable Diseases Division, UK Health Security Agency, London, UK

\section{Abstract}

The duration of immunity after first SARS-CoV-2 infection and the extent to which prior immunity prevents reinfection is uncertain and remains an important question within the context of new variants.

Using a retrospective population-based matched observational study approach, we identified cases with a first PCR positive test between 01 March 2020 and 30 September 2020 and cases were matched by age, sex, upper tier local authority of residence and testing route to individuals testing negative in the same week (controls) by PCR. After a 90-day pre-follow up period for cases and controls, any subsequent positive tests up to 31 December 2020 and deaths within 28 days of testing positive were identified, this encompassed an essentially vaccine-free period.

There were 517,870 individuals in the matched cohort with 2,815 reinfection cases and 12,098 first infections. The protective effect of a prior SARS-CoV-2 PCR-positive episode was $78 \%$ (OR $0.22,0.21-0.23$ ). Protection rose to $82 \%$ (OR $0.18,0.17-0.19$ ) after a sensitivity analysis excluded 934 individuals with a first test between March and May and a subsequent positive test between June and September 2020. Amongst individuals testing positive by PCR during follow-up, reinfection cases had $77 \%$ lower odds of symptoms at the second episode (adjusted OR $0.23,0.20-0.26$ ) 
medRxiv preprint doi: https://doi.org/10.1101/2022.01.10.22268896; this version posted January 10, 2022. The copyright holder for this preprint (which was not certified by peer review) is the author/funder, who has granted medRxiv a license to display the preprint in All rights reserved. No reuse allowed without permission.

and $45 \%$ lower odds of dying in the 28 days after reinfection (adjusted OR 0.55 , $0.42-0.71)$

Prior SARS-CoV-2 infection offered protection against reinfection in this population. There was some evidence that reinfections increased with the Alpha variant compared to the wild-type SARS-CoV-2 variant highlighting the importance of continued monitoring as new variants emerge.

\section{Financial support}

This research received no specific grant from any funding agency, commercial or not-for-profit sectors.

Conflicts of Interest: None

\section{Data Availability Statement}

The national datasets used in this research contain personal identifiable information which was used to link test results and are not available to the public. Aggregated positive test numbers are published daily on the UK coronavirus dashboard (https://coronavirus.data.gov.uk/) and UKHSA publishes data on numbers of possible reinfections in the National flu and COVID-19 surveillance reports (https://www.gov.uk/government/statistics/national-flu-and-covid-19-surveillancereports-2021-to-2022-season). Any additional data requests should be made through the corresponding author. 
medRxiv preprint doi: https://doi.org/10.1101/2022.01.10.22268896; this version posted January 10, 2022. The copyright holder for this preprint (which was not certified by peer review) is the author/funder, who has granted medRxiv a license to display the preprint in All rights reserved. No reuse allowed without permission.

\section{Introduction}

As of 10 December 2021, 267.9 million COVID-19 cases and 5.3 million associated deaths have been reported globally to the World Health Organisation(1). The first case of COVID-19 disease in the UK was confirmed in January 2020 and by the end of that same year, 52 million PCR tests had been performed with 2.65 million individuals testing positive at least once and 76,406 deaths reported within 28 days of a positive result. Reinfection is associated with seasonal human coronaviruses such as the common cold and there is a recognised need to understand the risk of reinfection in individuals that have recovered from COVID-; a population that will continue to increase.

The duration of immunity after first SARS-CoV-2 infection and the extent to which prior immunity provides protection against disease or transmission remains uncertain. Potential cases of reinfection have been reported internationally(2-6). In England, possible reinfection cases are defined as individuals that have an interval of at least 90 days between two consecutive positive tests. As of 31 October 2021, there have been 72,264 possible reinfections in England out of 7.8 million first positive tests. Confirmed reinfections are those with genetically distinct specimens at each episode, however these require sequencing at each episode so currently only a small proportion of possible reinfections can be confirmed. The most recent data up to 31 October 2021 included 441 confirmed reinfections(7).

An analysis of a large, multi-centre, prospective cohort study of hospital healthcare workers in the UK, found that a prior history of SARS-CoV-2 infection was associated with an $84 \%$ (95\% Cl: $81 \%-87 \%)$ lower risk of infection during 7 months of follow up(8). Similarly, a population-based study in Denmark found prior infection 
medRxiv preprint doi: https://doi.org/10.1101/2022.01.10.22268896; this version posted January 10, 2022. The copyright holder for this preprint (which was not certified by peer review) is the author/funder, who has granted medRxiv a license to display the preprint in All rights reserved. No reuse allowed without permission.

conferred $80 \%$ protection against reinfection in those aged 65 years and younger but only $47 \%$ protection against reinfection in those aged 65 years or older(9). A study of 43,000 individuals in Qatar estimated 95.2\% (95\% Cl: $94.1-96.0 \%)$ protection against reinfection(10). A retrospective cohort study of patients in a health system in Ohio and Florida found that the protection offered from prior infection to reinfection was $81.8 \%$ (95\% Cl: $76.6-85.8)$ at $\geq 90$ days after initial testing(11). The protection against symptomatic infection was $84.5 \%$ (95\% Cl: $77.9-89.1)$. A French study of SARS-CoV-2 screening tests found $42.6 \%$ of patients presented a similar clinical status upon reinfection (after $\geq 90$ days), $29.5 \%$ had a milder form of the disease and $27.8 \%$ worsened from asymptomatic to mild or severe disease(12).

The emergence of the Alpha(13), Beta(14), Gamma(15), Delta(16) and most recently Omicron (17) SARS-CoV-2 variants was a cause for concern, not only for the apparent increased transmissibility of subsequent variants $(13,18)$, associated with mutations in the spike protein $(19,20)$ but also for the increased risk of hospitalisation(21) and the potential to escape the immune response(22-27). It is important to understand if both natural and vaccine-acquired immunity provides protection from SARS-CoV-2 variants.

Using national testing datasets in England we identified people who tested PCR positive for SARS-CoV-2 for the first time between 01 March 2020 and 30 September 2020, as cases. These individuals were matched one-to-one to controls with a negative test result in the same week of test and tested via the same testing route with the same demographic characteristics of age (in years), sex and upper tier local authority of residence. We then looked at the risk in both case and control groups of reporting a positive PCR test within a predetermined follow up period starting 90 days after the last COVID-19 PCR positive test of the cases up until 31 
medRxiv preprint doi: https://doi.org/10.1101/2022.01.10.22268896; this version posted January $10,2022$. The copyright holder for this preprint (which was not certified by peer review) is the author/funder, who has granted medRxiv a license to display the preprint in All rights reserved. No reuse allowed without permission.

December 2020. This period therefore predated COVID-19 vaccine effects as vaccination began on 8 December 2020 in highest priority groups and anti-spike IgG levels mature over the 2-4 weeks after the first dose(28).

\section{Methods}

Study population and matching

The main analysis was a retrospective population-based matched observational study. COVID-19 is a notifiable disease and all laboratories in England are legally obliged to report all SARS-CoV-2 positive test results to Public Health England (PHE) and its successor, the UK Health Security Agency (UKHSA) through the Second Generation Surveillance System (SGSS)(29). The Unified Dataset (USD) consolidates data on positive tests from SGSS with national negative test data on an individual level. All SARS-CoV-2 testing undertaken by NHS or PHE laboratories for hospitalised patients or routine checks for healthcare workers are reported through pillar 1. Testing within the wider community for people reporting symptoms and requesting a test, regular testing of care home residents and their staff are reported through pillar 2.

Due to the limited number of paediatric reinfection cases identified in 2020, individuals in England aged 10 years or older were selected based on a first SARSCoV-2 positive PCR test result between 01 March 2020 and 30 September 2020. This ensured that those selected with a positive test, and those matched with an initial negative PCR result, had at least 90 days to become a reinfection or first infection respectively before the end of the study period on 31 December 2020 and enabled review of reinfection risk prior to widespread introduction of vaccination in England. Upper tier local authority of residence was derived from the patient's 
medRxiv preprint doi: https://doi.org/10.1101/2022.01.10.22268896; this version posted January $10,2022$. The copyright holder for this preprint (which was not certified by peer review) is the author/funder, who has granted medRxiv a license to display the preprint in All rights reserved. No reuse allowed without permission.

postcode or, if this was not available, then from their GP's postcode. Individuals with missing postcodes or with the same postcodes as their testing laboratory were excluded.

To be eligible, cases could not test positive for a period of 90 days after the latest positive PCR test from their first COVID-19 episode. Anyone who remained PCR positive for longer than 60 days was excluded from analysis as a possible case of persistent infection. All individuals were linked with the Personal Demographics Service (PDS) of the NHS spine which stores demographic information including deaths for all NHS patients(30). We excluded all participants that died before the end of their assigned pre-follow-up 90-day period and those that could not be linked to PDS.

Two rounds of matching were carried out to match PCR-positive cases to individuals testing PCR negative in the same week with the same sex, age in years, pillar test route (community or hospital-based testing) and upper tier local authority [Figure 1]. The selection of controls from within the national testing dataset enabled identification of controls from the same population as the cases with assumed similar risk of infection to their matched cases. Individual matching was undertaken to directly compare the rates of infection while excluding potential confounders. Cases that had multiple positive tests after their first positive test for a period of less than 60 days were matched to an individual that tested negative based on first PCR test date but the study follow-up period for both the case and matched control started 90 days after the last positive test of the first episode of the case [Supplementary figure 1]. To be eligible, matched controls could not have tested positive before their selection, they could not have a positive result for the 90 day or full pre-follow up period 
medRxiv preprint doi: https://doi.org/10.1101/2022.01.10.22268896; this version posted January 10, 2022. The copyright holder for this preprint (which was not certified by peer review) is the author/funder, who has granted medRxiv a license to display the preprint in All rights reserved. No reuse allowed without permission.

required by their matched case. Matched controls were also linked to PDS and were excluded if they died during the pre-follow up period or could not be found on PDS.

We matched on a month by month basis to exclude matched negatives from becoming part of the study for a second time if they tested negative again after they had already been linked to a case from an earlier month. Both the cases and controls were included if they had previous negative tests prior to inclusion in the study, however neither could have had a prior positive test. Additional details on both cases and controls were extracted including whether they had indicated symptoms at their first test, their ethnicity which was obtained from the National Immunisation Management System (NIMS) and their Indices of Multiple Deprivation (IMD) quintile which was obtained from the individuals' postcode and linked to the 2019 indices of deprivation data; an IMD quintile of 1 represents individuals with postcodes in the most deprived areas.

\section{Follow-up period}

The follow up period started after the 90-day pre-follow up period was completed and continued until 31 December 2020. The start of the follow up period varied depending on when the case first tested positive. Cases that first tested positive on 1 March 2020 had an earliest start date of 30 May 2020 for example, while some cases that first tested positive in September 2020 had their follow up period start in December 2020.

The cases and controls were linked by NHS number and via their unique identifier assigned by SGSS to all records of positive SARS-CoV-2 test results to find any subsequent PCR-positive test results. We used lookup tables to match the controls' unique identifier from the USD to their unique identifier in SGSS. Reinfection cases 
medRxiv preprint doi: https://doi.org/10.1101/2022.01.10.22268896; this version posted January $10,2022$. The copyright holder for this preprint (which was not certified by peer review) is the author/funder, who has granted medRxiv a license to display the preprint in All rights reserved. No reuse allowed without permission.

were identified from the main SGSS dataset through identification of 90-day or longer intervals between sequential positive results for the same individual and this data was linked to our case data via NHS number and unique identifier.

We extracted extra information from PCR tests in the follow up period including whether it was community or hospital-based testing and, for those individuals that were tested through community testing, we also obtained information on whether the participant was symptomatic together with data on the PCR results for the target genes. Three of the four Lighthouse laboratories used a diagnostic assay that does not detect a deletion of amino acids 69 and 70 of the spike protein, also known as $S$ gene target failure (SGTF). By 15 November 2020, S gene target failure became a reliable proxy for the Alpha (Kent B.1.1.7) variant that emerged in the UK in September and was associated with increased infectivity compared to the wild-type SARS-CoV-2 variant. We identified deaths up to 60 days beyond the end of the follow up period using PDS records.

Controls that subsequently tested positive were excluded from the case population.

\section{$\underline{\text { Statistical analysis }}$}

We used descriptive analysis to describe the population testing positive during the follow up period up. We carried out logistic regression to give the univariable odds ratios for testing positive for each of the matching variables, ethnicity and IMD quintile. The upper tier local authorities were grouped into the nine UKHSA regions for the analysis [Table 1].

Conditional logistic regression was used to take into account the matching design and to give an adjusted odds ratio for the cases and controls testing positive during the follow up period. We added predictors that were not matched (ethnicity, IMD 
medRxiv preprint doi: https://doi.org/10.1101/2022.01.10.22268896; this version posted January $10,2022$. The copyright holder for this preprint (which was not certified by peer review) is the author/funder, who has granted medRxiv a license to display the preprint in All rights reserved. No reuse allowed without permission.

quintile) into the conditional model to test for confounding. As the conditional regression model already accounted for the matched variables, these were not included in the final model.

A sensitivity analysis was done by splitting the follow up time into 30-day groupings to compare the odds of testing positive in the cases compared to the controls during each 30 days of follow up while excluding those that died or tested positive before the start of each time point. We carried out conditional logistic regression on each 30-day time point while stratifying by month to identify all time-related effects.

Secondary outcomes within the population that tested positive during the follow-up period were also monitored. We used logistic regression to compare the odds of dying within 28 days, odds of dying within 60 days, odds of symptomatic infection and odds of second test being $S$ gene-negative between cases and controls. We used logistic regression for this analysis instead of conditional logistic regression due to the small numbers of matched pairs where each of the matched pair tested positive. Univariable odds ratios were calculated for each predictor and then a multivariable model was built. We tested additional variables one by one in the model with the likelihood ratio test. Age categories were regrouped into a binary variable with those aged over 50 and those aged 10-49 due to small numbers. Region was re-categorized for the $\mathrm{S}$ gene analysis into one region with London, South East and East of England and the other category with the rest of England. The first of these regional groupings roughly corresponded to the regions with Alpha variant dominance in November and December 2020.

\section{Post-hoc analysis}


medRxiv preprint doi: https://doi.org/10.1101/2022.01.10.22268896; this version posted January 10, 2022. The copyright holder for this preprint (which was not certified by peer review) is the author/funder, who has granted medRxiv a license to display the preprint in All rights reserved. No reuse allowed without permission.

After the sensitivity analysis, the dataset was trimmed for a post-hoc conditional logistic regression analysis which excluded 2,987 cases and their matched controls that had their first test in either March, April or May 2020 and then had a positive test or died in either the first 90 days (individuals from March), first 60 days (individuals from April) or first 30 days (Individuals from May) of follow up. This corresponds to excluding 934 individuals that tested positive in the summer months between June and September 2020; these cases and controls were excluded due to the stratified results of the conditional regression of the whole dataset and concerns about the quality and limited testing during the early months of the pandemic [Figure 2].

Statistical analysis was carried out in STATA version 15.1, linkage to SGSS and USD datasets was carried out in Microsoft SQL server management studio 18.

\section{Results}

\section{Study population and matching}

There were 419,978 individuals that tested positive by PCR for SARS-CoV-2 between March and September 2020 in England. We excluded 22,648 individuals that either had missing demographic information or were under 10 years old, 1,911 individuals with persistent infection, 40,983 individuals that died in the pre-follow up period and 43,408 individuals that could not be found on PDS. The remaining 311,028 individuals with positive PCR tests underwent two rounds of matching to a test-negative with the same sex, age, week of test, upper tier local authority of residence and pillar of testing. The first round of matching led to 66,827 exclusions of the matched controls due to the controls either testing positive in the pre-follow up 
medRxiv preprint doi: https://doi.org/10.1101/2022.01.10.22268896; this version posted January 10, 2022. The copyright holder for this preprint (which was not certified by peer review) is the author/funder, who has granted medRxiv a license to display the preprint in All rights reserved. No reuse allowed without permission.

period, dying within 90 days of their first test, not linking in PDS or being included in the study twice and therefore a second matching round was undertaken for these individuals [Figure 1]. There were 638 negative controls that became positive cases and so these individuals were kept in the control population but were removed from the case population along with their matched control.

The final cohort consisted of 258,935 successfully matched cases giving a total of 517,870 individuals.

\section{Descriptive analysis}

Figure 2 shows the distribution by week of the 517,870 individuals included in the analysis by date of first test. There was a peak in April 2020 and then a lull in the summer months with a subsequent increase in positive tests from September 2020. Data for the last week of September is incomplete as 30 September 2020 fell on a Wednesday and so there was only data for three days instead of seven.

During the follow up period 14,913 individuals had a positive test; 2,815 were reinfections in the cases and the remaining 12,098 positive tests were first infections in the controls. Cases had $78 \%$ lower odds of testing positive in the follow up period than controls (univariable odds ratio $0.22,95 \% \mathrm{Cl} 0.22-0.23$ ). There was a peak in positive tests in the controls at the beginning of the follow up period and subsequent increase in positive tests around 100 days of follow up [Figure 3]. The distribution of test-positives in cases was more linear and remained lower than in controls. A decreasing number of individuals contributed to the analysis over time.

Based on the univariable analysis, men had $32 \%$ decreased odds (OR 0.68, 0.66 0.71) of testing positive in the follow-up period compared to women [Table 1], while those initially tested using community testing were also less likely to test positive in 
medRxiv preprint doi: https://doi.org/10.1101/2022.01.10.22268896; this version posted January 10, 2022. The copyright holder for this preprint (which was not certified by peer review) is the author/funder, who has granted medRxiv a license to display the preprint in All rights reserved. No reuse allowed without permission.

the follow up period (OR $0.70,0.67-0.72$ ) compared to those that had their first test in hospital-based testing. Children aged $10-19$ had $49 \%$ lower odds of testing positive (OR $0.51,0.47-0.56$ ) compared to adults aged $20-29$, while adults aged $80+$ were twice as likely to have a positive test (OR 2.02, 1.91-2.14). Individuals with Asian or Asian British (OR 0.85, 0.81-0.9), Black or Black British (OR 0.85, 0.770.94 ) and Mixed (OR $0.81,0.71-0.93)$ ethnicities had lower odds of testing positive compared to individuals with white ethnicities.

The results of the overall conditional logistic regression which takes into account the matching variables, found cases had $78 \%$ lower odds (OR $0.22,0.21-0.23$ ) of a positive test during the follow up period compared to controls [Table 2]. As the variables used for matching were taken into account by the model, they do not give an output within the conditional logistic regression model and so are not included in Table 2. Ethnicity and IMD quintile were not added to the multivariable conditional logistic regression model as they were not found to be significant confounders.

Once the dataset was split into different timepoints for a sensitivity analysis, viewing the odds ratios by month of first test revealed that the odds ratios vary by month of first test and follow-up time [Figure 4] with odds ratios as high as $3.25(1.06-9.97)$ in individuals that tested positive during the first 30 days of follow-up with their initial test from March. The higher odds ratios for individuals with first tests in March, April and May during the beginning of follow up corresponds to higher odds of testing positive for the cases than controls during the months of June, July, August and September.

The post-hoc analysis excluded 934 individuals that tested positive and 2,111 individuals that died. Those excluded had a first test during the months of March, 
medRxiv preprint doi: https://doi.org/10.1101/2022.01.10.22268896; this version posted January 10, 2022. The copyright holder for this preprint (which was not certified by peer review) is the author/funder, who has granted medRxiv a license to display the preprint in

All rights reserved. No reuse allowed without permission.

April and May and had an event during the 90-day, 60 day and 30-day time point respectively. After additionally excluding the matched case or control for these individuals, the final post-hoc dataset consisted of 511,896 individuals with 255,948 individuals in each matched cohort. After excluding these individuals, the odds of testing positive during the follow up period for the cases was $82 \%$ (OR $0.18,0.17$ 0.19) lower in cases than for controls.

\section{Secondary outcomes}

There were 3,376 deaths amongst controls and 3,031 deaths amongst cases in those that did not have a PCR-positive COVID test during the follow up period. Of the 13,979 individuals in the post-hoc analysis that tested positive during the follow up period, 608 controls (5.2\%) and 89 cases (3.9\%) died within 28 days of the positive test and 703 (6.0\%) controls and 111 (4.9\%) of cases died within 60 days of the positive test [Table 3]. Individuals that were aged over 50 had more than 57 times the odds of dying compared to individuals aged 10-49 (OR 57.5, 36.40-90.84) and men had twice the odds of dying compared to women (OR 2.07, $1.78-2.41$ ). The testing route of the first test was associated with dying as individuals tested through community testing had $76 \%$ lower odds of dying after a positive test compared to individuals that had their first test in hospital (OR $0.24,0.20-0.28)$. After adjusting for sex, age, route of first test, month of first test and ethnicity, the cases went from having $25 \%$ lower odds of dying (OR $0.75,0.60-0.94)$ to $45 \%$ lower odds of dying within 28 days of their reinfection compared to the odds of controls dying after their first infection (adjusted OR 0.55, 0.42-0.71).

Of those individuals in the post-hoc dataset that tested positive during the follow up period, symptom data was recorded for $75 \%$ of individuals, and the percentage of 
medRxiv preprint doi: https://doi.org/10.1101/2022.01.10.22268896; this version posted January 10, 2022. The copyright holder for this preprint (which was not certified by peer review) is the author/funder, who has granted medRxiv a license to display the preprint in All rights reserved. No reuse allowed without permission.

missing symptom data varied by age, month of first test, region and first test route [Supplementary table 1]. All tests with symptom data would have all been taken through the community testing route. Of controls that tested positive, 5,860 (66.3\%) had symptoms, this compares to 499 (30.0\%) of the reinfection cases. Men were more likely to report symptoms on their positive test with 1.8 times the odds of having symptoms at their second test compared to women (OR 1.75, 1.61- 1.91), and all regions of England had lower odds of having symptoms compared to individuals from London. Individuals with Asian or British Asian ethnicity had twice the odds as individuals with White ethnicities to report symptoms (OR 2.12, 1.852.43) while individuals with Black or Black British ethnicities had $38 \%$ lower odds of reporting symptoms (OR $0.62,0.50-0.77)$. After adjusting for sex, age group, month of first test, region and ethnicity, the odds of cases having symptoms during their reinfection was $77 \%$ (adjusted OR $0.23,0.20-0.26$ ) lower than for controls having symptoms during their first test.

The S-gene target failure (SGTF) was used as a proxy for individuals infected with the Alpha variant from 15 November 2020. There were 8,435 individuals that tested positive from 15 November, of these $37 \%$ had S-gene data available, the percentage of missing S-gene data varied by first test type, region, age, month of first test, first test route and ethnicity [Supplementary table 2]. There were 159 (54.6\%) reinfection cases and 1,205 (42.5\%) controls with SGTF. Individuals that lived outside of London, the South East and East of England had 84\% lower odds of having SGTF (OR $0.16,0.13-0.19$ ). Older adults aged above 50 years old had $19 \%$ lower odds of SGTF (OR 0.81, 0.69 -0.95). After adjusting for region, age group, month of first test and ethnicity, reinfection cases had 1.9 times the odds of having SGTF (indicative of 
medRxiv preprint doi: https://doi.org/10.1101/2022.01.10.22268896; this version posted January 10, 2022. The copyright holder for this preprint (which was not certified by peer review) is the author/funder, who has granted medRxiv a license to display the preprint in All rights reserved. No reuse allowed without permission.

the Alpha variant) compared to controls with their first test (adjusted OR 1.90, 1.432.51).

\section{Discussion}

Among our matched cohort of 517,870 individuals, there were 2,815 reinfection cases and 12,098 first infection cases up until 31 December 2020. Therefore, individuals with a prior SARS-CoV-2 PCR positive test had 78\% lower odds (OR $0.22,0.21-0.23)$ of having a second infection compared to individuals with no prior positive, from at least 90 days after their positive test up to a maximum of 9 months later. Protection increased to $82 \%$ lower odds (OR $0.18,0.17-0.19$ ) in our post-hoc analysis. These findings demonstrate a baseline of protection from a prior SARSCoV-2 infection against reinfection before the widespread introduction of vaccination against COVID-19 in December 2020. This finding is in line with the results of a Danish study over a similar timeframe which found $80.5 \%$ protection against a second infection among 525,339 individuals that were followed in the second wave of the pandemic(9). Our findings are consistent with the SIREN study which followed healthcare workers in the UK and found that a previous infection was associated with a $84 \%$ lower risk of infection(8). The SIREN study was based on a similar period with data extracted up to January 2021, however the health care worker population were regularly tested and probably more likely to be exposed to COVID-19 than the general population. Our findings show that the protective effect of previous infection in the general population is at least very similar to that in health care workers, though we could be underestimating the protection as our study relies on individuals seeking COVID-19 testing and we postulate that seeking testing is a health seeking behaviour that could change after previous PCR confirmed SARS-CoV-2 infection. In those with a PCR-positive test during the follow-up period, the reinfection cases 
medRxiv preprint doi: https://doi.org/10.1101/2022.01.10.22268896; this version posted January 10, 2022. The copyright holder for this preprint (which was not certified by peer review) is the author/funder, who has granted medRxiv a license to display the preprint in All rights reserved. No reuse allowed without permission.

appeared to have milder disease with $77 \%$ lower odds of having symptoms at their second test (adjusted OR 0.23, 0.20-0.26). Age was significantly associated with death in all infections in the follow-up period with adults aged above 50 having 57 times the odds of dying (OR 57.5, 36.40-90.84) compared to younger adults and children aged 10-49 in the 28 days after testing positive. Cases of reinfection had $45 \%$ lower odds of dying in the 28 days after their reinfection compared to the controls (adjusted OR 0.55, 0.42-0.71).

The sensitivity analysis further investigated the odds of testing positive at different time points by month of first test thus revealing that there were higher odds of testing positive in the cases compared to the controls within individuals that had their first test in March, April and May and then had a positive test during the follow up period in June, July and August and September. The reasons for this disparity and high number of reinfections compared to the overall protective effect of prior SARS-CoV-2 infection are uncertain, however, it is possible that the population who were tested during the beginning of the pandemic were fundamentally different and were more likely to be elderly, hospitalised patients due to limited testing. Indeed $50.1 \%$ of individuals with a first test in March, April or May were aged over 50 years compared to $27.1 \%$ of individuals with a first test in June-September and $59.1 \%$ of individuals tested in these early months were tested through hospital testing compared to only $12.6 \%$ of individuals with first test in June-September. The uncertain reinfection cases occurred soon after the end of the 90-day pre-follow up period and so this could mean that some are persistent infections in this specific population. Cycle threshold $(\mathrm{Ct})$ values are obtained from a PCR test and can give an indication of how much viral genetic material there is in a sample, a lower $\mathrm{Ct}$ value indicates that there is a higher concentration of virus, higher $\mathrm{Ct}$ values mean there is less virus and could 
medRxiv preprint doi: https://doi.org/10.1101/2022.01.10.22268896; this version posted January 10, 2022. The copyright holder for this preprint (which was not certified by peer review) is the author/funder, who has granted medRxiv a license to display the preprint in All rights reserved. No reuse allowed without permission.

indicate a persistent infection. However, Ct values are not recorded for all COVID-19 PCR tests in England and Ct values cannot be compared between different assays(31). As we do not adjust for comorbidities or look at $\mathrm{Ct}$ values in our analysis it is difficult to examine our hypothesis of persistent infections in detail, therefore we excluded 934 positive infections in cases and controls from the summer in the posthoc analysis. It is also possible that a small number of positive PCR results in that period could be false positives due to the low prevalence of COVID-19 at that time and resultant lower positive predictive value (PPV) of testing leading to nondifferential misclassification of the outcome in cases and controls.

Our analysis focuses on the 90-day criteria for possible reinfection and information is not available on the possible reinfection cases in our study to allow them to meet the confirmed reinfection definition. Large longitudinal cohort studies with epidemiological and virological information from each infection episode would be needed to differentiate cases that are SARS-CoV-2 RNA-positive over long periods of time from true cases of reinfection. It is also possible that individuals within the study could have had a reinfection over a shorter period than 90 days, the CDC also uses 45-day criteria for persons with COVID-19 like symptoms in addition to the 90 day interval criteria for individuals without symptoms, a 45 day interval was not investigated in our study due to incomplete symptom data(32).

Our results demonstrate that reinfection cases had almost twice the odds of being infected with the Alpha variant (adjusted OR 1.90, 1.43-2.51) compared to the controls, although these results should be interpreted with caution as we used S gene target failure as a proxy for the Alpha variant and there was a high proportion of missing S gene target failure data. The Delta variant emerged in spring 2021 and contributed to over $60 \%$ of sequenced cases in England by 17 May 2021(33). This 
medRxiv preprint doi: https://doi.org/10.1101/2022.01.10.22268896; this version posted January 10, 2022. The copyright holder for this preprint (which was not certified by peer review) is the author/funder, who has granted medRxiv a license to display the preprint in All rights reserved. No reuse allowed without permission.

was after the period covered by our analysis which focused on reinfections prior to the introduction of vaccines so that vaccination did not confound the results.

However, a UKHSA analysis found that the odds ratio of possible reinfection was higher with the Delta compared to the Alpha variant (OR 1.46, 1.03-2.05)(34), thus emphasising the need to monitor any increases in possible reinfection cases linked to a new variant. The emergence of Omicron highlights these concerns as analysis of routine surveillance data of almost 3 million individuals with a laboratory confirmed SARS-CoV-2 result from South Africa found that there was a greater risk of reinfection compared to primary infection during the current Omicron wave (hazard ratio $2.39,95 \% \mathrm{Cl} 1.88-3.11$ ) highlighting that Omicron can evade immunity, the study did not find evidence of increased reinfection for either the Beta and Delta variants (27).

As COVID-19 vaccine roll-out continues and some countries have started delivering booster programmes, it has become increasingly important to understand the impact of previous infection on the efficacy of COVID-19 vaccines and the need for boosting in a two-dose regimen. The COVID-19 vaccines currently in use trigger immune responses to the spike protein, however natural infection generates a broader humoral and cellular immune response with convalescent individuals demonstrating strong CD8+ T cell responses(35). The data on immune responses following PfizerBioNTech COVID-19 vaccination (BNT162b2) indicates that individuals with previous SARS-CoV-2 infection may generate stronger immune responses with more cross neutralising antibodies to one dose of BNT162b2 vaccine than compared to those without previous infection(36-39). There are concerns about waning protection postvaccination against the Delta variant with one study showing protection against symptomatic disease reduced to $47.3(95 \% \mathrm{Cl} 45$ to 49.6$)$ and $69.7(95 \% \mathrm{Cl} 68.7$ to 
medRxiv preprint doi: https://doi.org/10.1101/2022.01.10.22268896; this version posted January $10,2022$. The copyright holder for this preprint (which was not certified by peer review) is the author/funder, who has granted medRxiv a license to display the preprint in All rights reserved. No reuse allowed without permission.

70.5) for Vaxzevria and BNT162b2, respectively after 20 weeks(40). Early vaccine effectiveness estimates for Omicron suggest there is significantly lower vaccine effectiveness from two doses of vaccine against symptomatic disease caused by Omicron variant compared to Delta variant. However from two weeks after a BNT162b2 booster dose, vaccine effectiveness against symptomatic disease caused by Omicron variant increases to $71 \%$ for those with a Vaxzevria primary course and $76 \%$ for those with a BNT162b2 primary course (26). The role of prior infection in combination with breakthrough infection following vaccination to protect against Omicron infection is not yet well defined.

As the number of individuals with previous SARS-CoV-2 infection increases, we will continue to see more reinfection cases and therefore it is vital that we continue to monitor the duration and nature of protection against reinfection in populations with high vaccine coverage and different emerging variants. 
medRxiv preprint doi: https://doi.org/10.1101/2022.01.10.22268896; this version posted January $10,2022$. The copyright holder for this preprint (which was not certified by peer review) is the author/funder, who has granted medRxiv a license to display the preprint in perpetuity.

All rights reserved. No reuse allowed without permission.

Missing sex, age, postcode, or age under 10 , postcode source from the lab or test date before March 2020

Persistent infection

Died within 90 day follow up

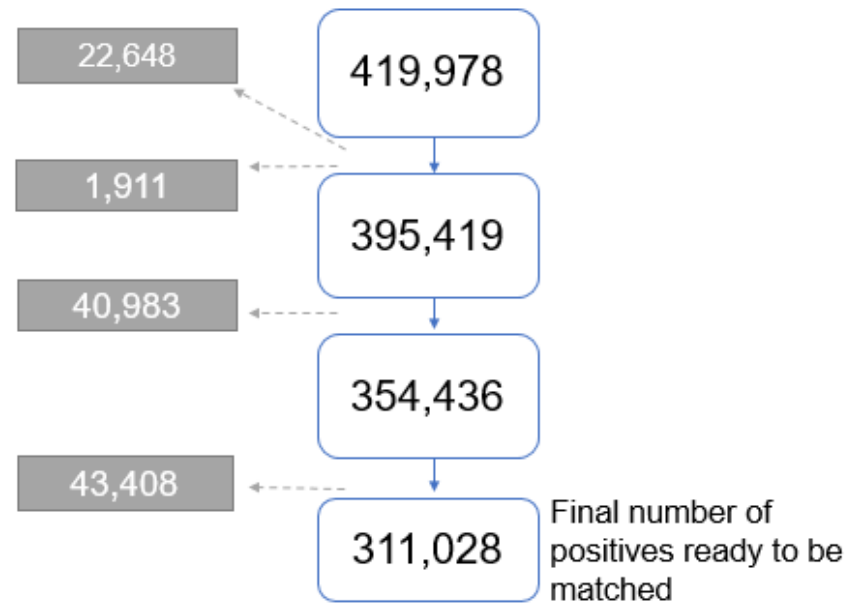
period

Final number of negatives to be matched (number may contain duplicates)

Individuals could not be found on PDS

\section{7,926}

$\sim 6$ million test negatives from March- Sep 2020 to be matched

\section{First round matching}

Cases could not be matched to any control

66,827 to be re-matched because:

- Matched negative tested positive during pre-follow up period

\section{3,102} Matched negative died in pre-follow up period

- Matched negative in analysis twice

- Matched negative could not be found on PDS

- Matched negative became a case so had to remove the case from the dataset

\section{Second round matching}

Matched control
excluded so case also
excluded
$\begin{aligned} & \text { Final number } \\ & \text { successfully matched in } \\ & \text { second round }\end{aligned}$

Figure 1 Diagram detailing the cleaning and matching steps taken to select the final study population 
medRxiv preprint doi: https://doi.org/10.1101/2022.01.10.22268896; this version posted January $10,2022$. The copyright holder for this preprint (which was not certified by peer review) is the author/funder, who has granted medRxiv a license to display the preprint in All rights reserved. No reuse allowed without permission.

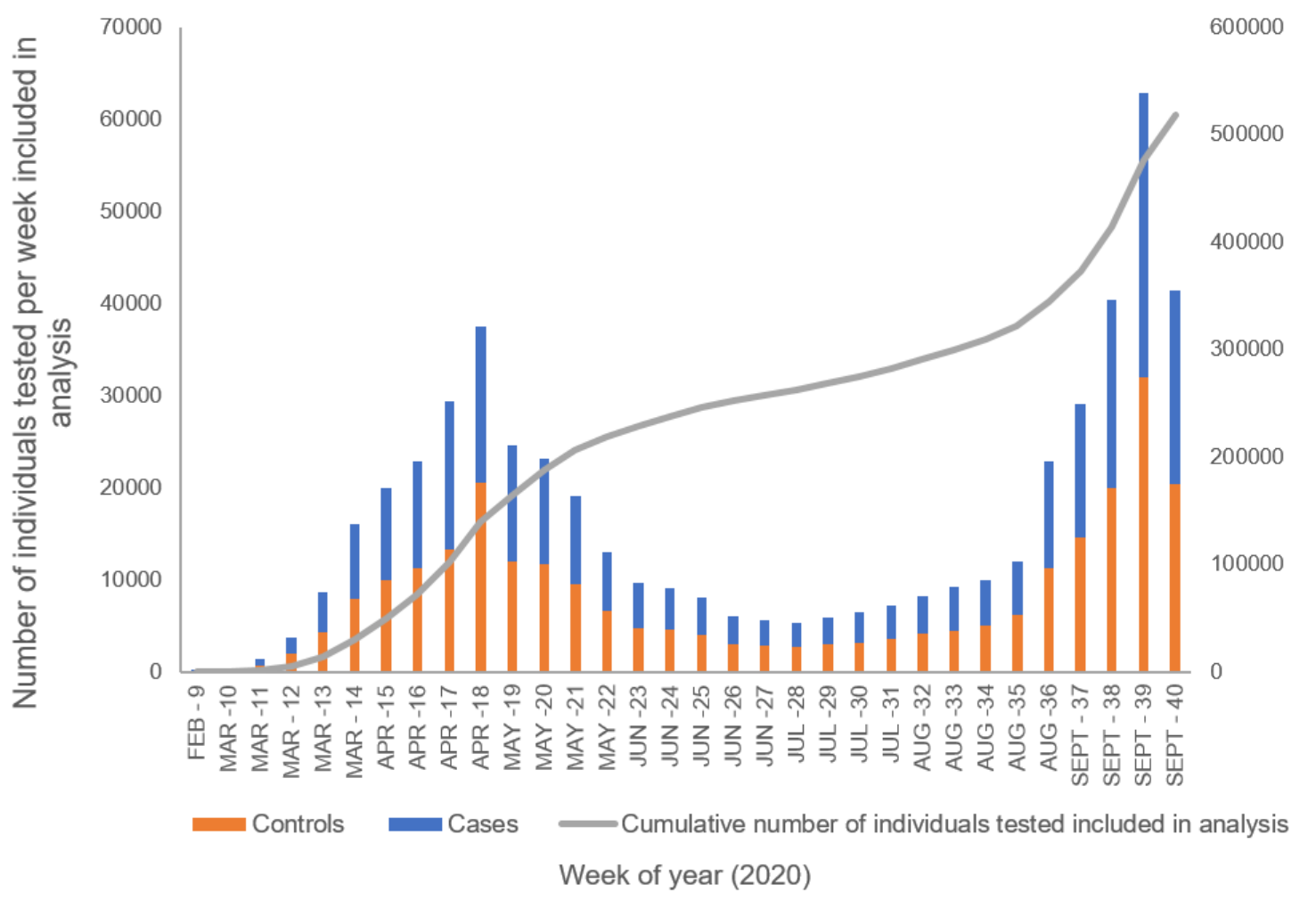

Figure 2 Distribution by week of test for total individuals (cases and controls) included in final analysis 
medRxiv preprint doi: https://doi.org/10.1101/2022.01.10.22268896; this version posted January 10, 2022. The copyright holder for this preprint (which was not certified by peer review) is the author/funder, who has granted medRxiv a license to display the preprint in

All rights reserved. No reuse allowed without permission.

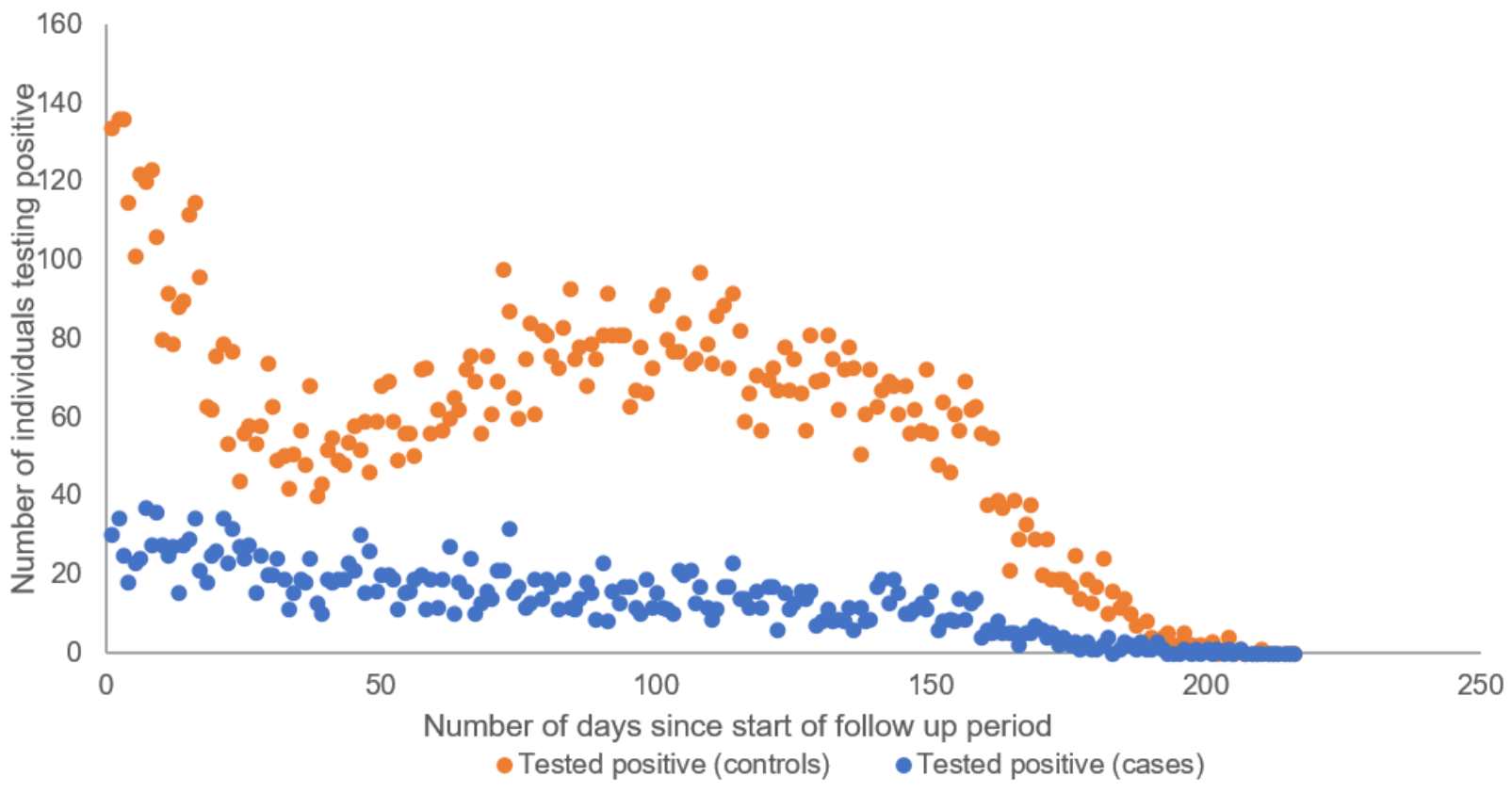

Figure 3 Distribution of positive tests during follow up period by days of follow up for cases and controls. The follow up period does not include the pre-follow up 90 day period after first tests 
medRxiv preprint doi: https://doi.org/10.1101/2022.01.10.22268896; this version posted January $10,2022$. The copyright holder for this preprint (which was not certified by peer review) is the author/funder, who has granted medRxiv a license to display the preprint in perpetuity.

All rights reserved. No reuse allowed without permission.
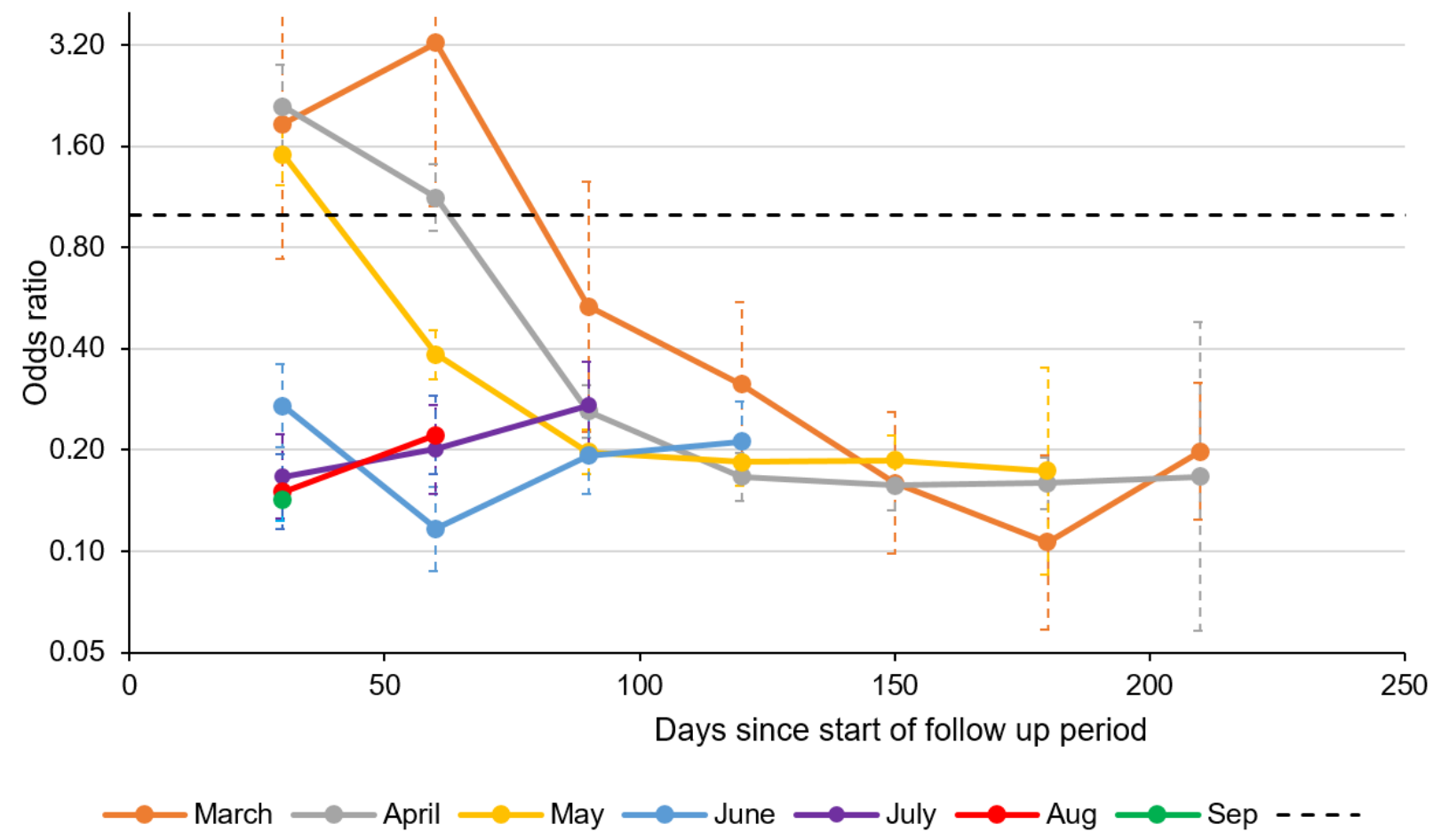

Figure 4 Adjusted odds ratios of a reinfection compared to a first infection according to month of original positive or negative test 
medRxiv preprint doi: https://doi.org/10.1101/2022.01.10.22268896; this version posted January 10, 2022. The copyright holder for this preprint (which was not certified by peer review) is the author/funder, who has granted medRxiv a license to display the preprint in

All rights reserved. No reuse allowed without permission.

Table 1 Description of study population in terms of matching variables (first test pillar, sex, age, month of first test, region), ethnicity, IMD quintiles and distribution of the outcome, tested positive, with univariable odds ratios from logistic regression

\begin{tabular}{|c|c|c|c|c|c|c|c|}
\hline \multirow[b]{2}{*}{ First test } & $\begin{array}{l}\text { Total in } \\
\text { pop. } \\
\text { Cases }\end{array}$ & $\begin{array}{l}\text { study } \\
\text { Controls }\end{array}$ & \multirow[t]{2}{*}{$\begin{array}{c}\text { Number } \\
\text { without } \\
\text { positive } \\
\text { test }\end{array}$} & \multirow[t]{2}{*}{$\begin{array}{l}\text { Number } \\
\text { with a } \\
\text { positive } \\
\text { test (\%) }\end{array}$} & \multicolumn{2}{|c|}{$\begin{array}{l}\text { Univariable OR } \\
(95 \% \mathrm{Cl})\end{array}$} & \multirow[t]{2}{*}{$\begin{array}{l}P \\
\text { value }\end{array}$} \\
\hline & & & & & & & \\
\hline Negative (Control) & & 258,935 & 246,837 & $\begin{array}{r}12,098 \\
(4.7)\end{array}$ & & 1 & \\
\hline Positive (Case) & 258,935 & & 256,120 & $2,815(1.1)$ & $0.22(0.22$ & $0.23)$ & $<0.001$ \\
\hline \multicolumn{8}{|l|}{ First test route } \\
\hline Hospital testing & 83,702 & 83,702 & 161,377 & 6,027 (3.6) & & 1 & \\
\hline Community testing & 175,233 & 175,233 & 341,580 & $8,886(2.5)$ & $0.70(0.6$ & $\begin{array}{ll}67 & 0.7\end{array}$ & $<0.001$ \\
\hline \multicolumn{8}{|l|}{ Sex } \\
\hline $\mathrm{F}$ & 150,614 & 150,614 & 291,262 & 9,966 (3.3) & & 1 & \\
\hline M & 108,321 & 108,321 & 211,695 & 4,947 (2.3) & $0.68(0.66$ & $0.71)$ & $<0.001$ \\
\hline \multicolumn{8}{|l|}{ Age } \\
\hline $10-19$ years & 24,298 & 24,298 & 47,915 & $681(1.4)$ & $0.51(0.47$ & $0.56)$ & $<0.001$ \\
\hline $20-29$ years & 52,360 & 52,360 & 101,891 & $2,829(2.7)$ & & 1 & \\
\hline 30-39 years & 45,597 & 45,597 & 88,617 & $2,577(2.8)$ & $1.05(0.99$ & 1.11) & 0.094 \\
\hline $40-49$ years & 41,271 & 41,271 & 80,054 & $2,488(3.0)$ & $1.12(1.06$ & 1.18) & $<0.001$ \\
\hline $50-59$ years & 42,504 & 42,504 & 82,425 & $2,583(3.0)$ & $1.13(1.07$ & 1.19) & $<0.001$ \\
\hline $60-69$ years & 21,099 & 21,099 & 41,166 & $1,032(2.4)$ & $0.9(0.84$ & $0.97)$ & 0.006 \\
\hline $70-79$ years & 13,065 & 13,065 & 25,400 & $730(2.8)$ & $1.04(0.95$ & 1.12) & 0.412 \\
\hline 80 plus years & 18,741 & 18,741 & 35,489 & $1,993(5.3)$ & $2.02(1.91$ & 2.14) & $<0.001$ \\
\hline \multicolumn{8}{|l|}{ Month of first test } \\
\hline March & 8,842 & 8,842 & 17,153 & $531(3.0)$ & $3.6(3.26$ & 3.97) & $<0.001$ \\
\hline April & 54,554 & 54,554 & 104,370 & $4,738(4.3)$ & $5.28(4.99$ & $5.58)$ & $<0.001$ \\
\hline May & 46,207 & 46,207 & 87,861 & 4,553 (4.9) & $6.02(5.69$ & $6.38)$ & $<0.001$ \\
\hline June & 17,375 & 17,375 & 33,149 & $1,601(4.6)$ & $5.61(5.24$ & $6.02)$ & $<0.001$ \\
\hline July & 13,396 & 13,396 & 25,852 & $940(3.5)$ & $4.23(3.9$ & $4.58)$ & $<0.001$ \\
\hline August & 21,255 & 21,255 & 41,620 & $890(2.1)$ & $2.49(2.29$ & $2.7)$ & $<0.001$ \\
\hline September & 97,306 & 97,306 & 192,952 & $1,660(0.9)$ & & 1 & \\
\hline \multicolumn{8}{|l|}{ Region } \\
\hline London & 27,790 & 27,790 & 53,973 & $1,607(2.9)$ & & 1 & \\
\hline East Midlands & 23,731 & 23,731 & 45,888 & 1,574 (3.3) & $1.15(1.07$ & 1.24) & $<0.001$ \\
\hline East of England & 21,665 & 21,665 & 42,044 & $1,286(3.0)$ & $1.03(0.95$ & 1.11) & 0.48 \\
\hline
\end{tabular}


medRxiv preprint doi: https://doi.org/10.1101/2022.01.10.22268896; this version posted January 10,2022 . The copyright holder for this preprint (which was not certified by peer review) is the author/funder, who has granted medRxiv a license to display the preprint in All rights reserved. No reuse allowed without permission.

\begin{tabular}{|c|c|c|c|c|c|c|c|}
\hline North East & 19,182 & 19,182 & 37,302 & $1,062(2.8)$ & $0.96(0.88$ & 1.03) & 0.26 \\
\hline North West & 64,124 & 64,124 & 124,956 & $3,292(2.6)$ & $0.88(0.83$ & $0.94)$ & $<0.001$ \\
\hline South East & 26,427 & 26,427 & 51,000 & $1,854(3.5)$ & $1.22(1.14$ & 1.31) & $<0.001$ \\
\hline South West & 12,614 & 12,614 & 24,636 & $592(2.3)$ & $0.81(0.73$ & $0.89)$ & $<0.001$ \\
\hline West Midlands & 29,049 & 29,049 & 56,420 & $1,678(2.9)$ & $1(0.93$ & 1.07) & 0.98 \\
\hline $\begin{array}{r}\text { Yorkshire and } \\
\text { Humber }\end{array}$ & 34,353 & 34,353 & 66,738 & $1,968(2.9)$ & $0.99(0.93$ & 1.06) & 0.78 \\
\hline \multicolumn{8}{|l|}{ Ethnicity } \\
\hline White & 193,299 & 171,624 & 353,910 & $\begin{array}{r}11,013 \\
(3.0)\end{array}$ & & 1 & \\
\hline Asian or Asian British & 22,506 & 41,410 & 62,266 & $1,650(2.6)$ & $0.85(0.81$ & $0.9)$ & $<0.001$ \\
\hline Black or Black British & 8,143 & 9,673 & 17,356 & $460(2.6)$ & $0.85(0.77$ & $0.94)$ & 0.001 \\
\hline Mixed & 4,040 & 4,499 & 8,328 & 211 (2.5) & $0.81(0.71$ & $0.93)$ & 0.003 \\
\hline Other ethnic groups & 6,148 & 7,063 & 12,851 & $360(2.7)$ & $0.9(0.8$ & 31 1) & 0.053 \\
\hline Missing & 24,799 & 24,666 & 48,246 & 1,219 & & & \\
\hline \multicolumn{8}{|l|}{ IMD quintiles } \\
\hline 1 & 68,403 & 73,217 & 137,497 & $4,123(2.9)$ & & 1 & \\
\hline 2 & 54,918 & 58,484 & 110,038 & 3,364 (3.0) & $1.02(0.97$ & 1.07) & 0.41 \\
\hline 3 & 48,278 & 47,979 & 93,474 & 2,783 (2.9) & $0.99(0.95$ & 1.04) & 0.77 \\
\hline 4 & 46,281 & 42,580 & 86,305 & 2,556 (2.9) & $0.99(0.94$ & 1.04) & 0.63 \\
\hline 5 & 40,438 & 36,441 & 74,822 & 2,057 (2.7) & $0.92(0.87$ & $0.97)$ & 0.002 \\
\hline Missing & 617 & 234 & 821 & 30 & & & \\
\hline
\end{tabular}


medRxiv preprint doi: https://doi.org/10.1101/2022.01.10.22268896; this version posted January 10, 2022. The copyright holder for this preprint (which was not certified by peer review) is the author/funder, who has granted medRxiv a license to display the preprint in

All rights reserved. No reuse allowed without permission.

Table 2 Results from the conditional logistic regression with univariable odds ratios from the full dataset and from the post-hoc conditional logistic regression analysis. Matched variables are not included in this table as there is no output when included in a conditional model.

Post hoc analysis with trimmed dataset

\begin{tabular}{|c|c|c|c|c|c|c|c|c|}
\hline & $\begin{array}{l}\text { Did not test } \\
\text { positive }\end{array}$ & $\begin{array}{l}\text { Tested } \\
\text { positive }\end{array}$ & $\begin{array}{l}\text { Univariable } \\
\text { OR } \\
\text { conditional } \\
\text { model (95\% } \\
\text { Cl) }\end{array}$ & $\begin{array}{l}P \\
\text { value }\end{array}$ & $\begin{array}{r}\text { Did not } \\
\text { test } \\
\text { positive }\end{array}$ & $\begin{array}{l}\text { Tested } \\
\text { positive }\end{array}$ & $\begin{array}{r}\text { Univariable } \\
\text { OR } \\
\text { conditional } \\
\text { model (95\% } \\
\mathrm{Cl})\end{array}$ & $\begin{array}{r}P \\
\text { value }\end{array}$ \\
\hline \multicolumn{9}{|l|}{ First test } \\
\hline $\begin{array}{l}\text { Negative } \\
\text { (Control) }\end{array}$ & 246,837 & 12,098 & 1 & & 244,316 & 11,632 & 1 & \\
\hline $\begin{array}{r}\text { Positive } \\
\text { (Case) }\end{array}$ & 256,120 & 2,815 & $\begin{array}{r}0.22(0.21 \\
0.23)\end{array}$ & $<0.001$ & 253,708 & 2,240 & $\begin{array}{r}0.18(0.17 \\
0.19)\end{array}$ & $<0.001$ \\
\hline
\end{tabular}


medRxiv preprint doi: https://doi.org/10.1101/2022.01.10.22268896; this version posted January 10, 2022. The copyright holder for this preprint (which was not certified by peer review) is the author/funder, who has granted medRxiv a license to display the preprint in

All rights reserved. No reuse allowed without permission.

Table 3 Deaths within those that tested positive for COVID during the follow up period from post hoc dataset along with results from logistic regression for odds of dying at 28 days in cases compared to controls

\begin{tabular}{|c|c|c|c|c|c|}
\hline & $\begin{array}{r}\text { Tested } \\
\text { positive } \\
\text { in follow } \\
\text { up and } \\
\text { did not } \\
\text { die } \\
\text { within } \\
60 \text { days }\end{array}$ & $\begin{array}{r}\text { Died } \\
\text { within } 60 \\
\text { days } \\
\text { testing } \\
\text { positive } \\
(\%)\end{array}$ & $\begin{array}{r}\text { Died } \\
\text { within } 28 \\
\text { days } \\
\text { testing } \\
\text { positive } \\
(\%)\end{array}$ & $\begin{array}{r}\text { Univariable odds } \\
\text { ratio logistic } \\
\text { regression for } \\
\text { dying within } 28 \\
\text { days of testing } \\
\text { positive }\end{array}$ & $\begin{array}{r}\text { Multivariable odds } \\
\text { ratio logistic } \\
\text { regression for } \\
\text { dying within } 28 \\
\text { days of testing } \\
\text { positive }{ }^{*} \text { adjusted } \\
\text { for all variables } \\
\text { reported }\end{array}$ \\
\hline \multicolumn{6}{|l|}{ First test } \\
\hline \multirow{2}{*}{$\begin{array}{r}\text { Negative (Control) } \\
\text { Positive (Case) }\end{array}$} & 11,015 & $703(6)$ & $608(5.2)$ & 1 & 1 \\
\hline & 2,150 & $111(4.9)$ & 89 (3.9) & $0.75\left(\begin{array}{ll}0.6 & 0.94\end{array}\right)$ & $0.55\left(\begin{array}{lll}0.42 & 0.71)\end{array}\right.$ \\
\hline \multicolumn{6}{|l|}{ Sex } \\
\hline $\mathrm{F}$ & 8,870 & $409(4.4)$ & 347 (3.7) & 1 & \\
\hline M & 4,295 & $405(8.6)$ & $350(7.4)$ & 2.07 (1.78 2.41) & $2.08\left(\begin{array}{ll}1.73 & 2.5\end{array}\right)$ \\
\hline \multicolumn{6}{|l|}{ Age } \\
\hline Aged $10-49$ years & 8,192 & $23(0.3)$ & $19(0.2)$ & 1 & 1 \\
\hline Aged 50 and above & 4,973 & $\begin{array}{r}791 \\
(13.7)\end{array}$ & $\begin{array}{r}678 \\
(10.8)\end{array}$ & 57.5 (36.4 90.84) & $\begin{array}{r}37.67(22.79 \\
62.29)\end{array}$ \\
\hline \multicolumn{6}{|l|}{ First test route } \\
\hline Hospital testing & 4,964 & $593(10.7)$ & 501 (9) & 1 & 1 \\
\hline Community testing & 8,201 & $221(2.6)$ & $196(2.3)$ & $0.24\left(\begin{array}{ll}0.2 & 0.28\end{array}\right)$ & $0.31\left(\begin{array}{lll}0.24 & 0.38)\end{array}\right.$ \\
\hline \multicolumn{6}{|l|}{ Month of first test } \\
\hline March & 405 & $66(14)$ & $56(11.9)$ & 7.59 (4.79 12.04) & $1.09\left(\begin{array}{lll}0.63 & 1.88\end{array}\right)$ \\
\hline April & 3985 & $238(5.6)$ & $197(4.7)$ & $2.75(1.864 .08)$ & $0.62\left(\begin{array}{ll}0.39 & 0.96\end{array}\right)$ \\
\hline May & 3880 & $314(7.5)$ & $272(6.5)$ & $3.9(2.655 .74)$ & $1.21\left(\begin{array}{lll}0.79 & 1.85\end{array}\right)$ \\
\hline June & 1506 & $95(5.9)$ & $86(5.4)$ & 3.19 (2.08 4.89) & $1.3\left(\begin{array}{ll}0.81 & 2.09\end{array}\right)$ \\
\hline July & 903 & $37(3.9)$ & 31 (3.3) & $1.92(1.153 .2)$ & $1.07\left(\begin{array}{ll}0.6 & 1.91\end{array}\right)$ \\
\hline August & 858 & $32(3.6)$ & $26(2.9)$ & $1.69(0.992 .89)$ & $1.44\left(\begin{array}{ll}0.81 & 2.58\end{array}\right)$ \\
\hline September & 1,628 & $32(1.9)$ & $29(1.7)$ & 1 & $\begin{array}{l}1 \\
-1\end{array}$ \\
\hline \multicolumn{6}{|l|}{ Ethnicity } \\
\hline White & 10400 & $591(5.7)$ & $499(4.8)$ & 1 & 1 \\
\hline Asian or Asian British & 1,619 & $28(1.8)$ & $22(1.4)$ & $0.28\left(\begin{array}{ll}0.18 & 0.43\end{array}\right)$ & $0.51\left(\begin{array}{ll}0.33 & 0.8\end{array}\right)$ \\
\hline Black or Black British & 448 & $11(2.5)$ & $10(2.3)$ & $0.46\left(\begin{array}{ll}0.25 & 0.87\end{array}\right)$ & $0.56\left(\begin{array}{ll}0.29 & 1.09\end{array}\right)$ \\
\hline Mixed & 211 & $0(0)$ & $0(0)$ & & \\
\hline Other ethnic groups & 355 & $4(1.2)$ & $4(1.2)$ & $0.23\left(\begin{array}{lll}0.09 & 0.63\end{array}\right)$ & $0.34\left(\begin{array}{lll}0.12 & 0.94\end{array}\right)$ \\
\hline Missing & 1,001 & $\begin{array}{r}180 \\
(15.9)\end{array}$ & $\begin{array}{r}162 \\
(14.3)\end{array}$ & & \\
\hline \multicolumn{6}{|l|}{ Region } \\
\hline London & 1,473 & 70 (4.5) & $58(3.8)$ & 1 & \\
\hline East Midlands & 1,390 & $95(6.4)$ & $88(5.9)$ & $1.61(1.152 .26)$ & \\
\hline
\end{tabular}


medRxiv preprint doi: https://doi.org/10.1101/2022.01.10.22268896; this version posted January 10, 2022. The copyright holder for this preprint (which was not certified by peer review) is the author/funder, who has granted medRxiv a license to display the preprint in

All rights reserved. No reuse allowed without permission.

\begin{tabular}{|c|c|c|c|c|}
\hline East of England & 1,123 & 87 (7.2) & 71 (5.9) & $1.6\left(\begin{array}{ll}1.12 & 2.28\end{array}\right)$ \\
\hline North East & 922 & $63(6.4)$ & $49(5)$ & $1.34\left(\begin{array}{ll}0.91 & 1.98\end{array}\right)$ \\
\hline North West & 2,919 & 149 (4.9) & $125(4.1)$ & $1.09\left(\begin{array}{ll}0.79 & 1.49\end{array}\right)$ \\
\hline South East & 1,589 & $130(7.6)$ & $118(6.9)$ & $1.89\left(\begin{array}{ll}1.37 & 2.6\end{array}\right)$ \\
\hline South West & 501 & $35(6.5)$ & $31(5.8)$ & $1.57\left(\begin{array}{ll}1 & 2.46\end{array}\right)$ \\
\hline West Midlands & 1,447 & $116(7.4)$ & $96(6.1)$ & $1.68(1.22 .34)$ \\
\hline $\begin{array}{r}\text { Yorkshire and } \\
\text { Humber }\end{array}$ & 1,801 & 69 (3.7) & 61 (3.3) & $0.86\left(\begin{array}{ll}0.6 & 1.24\end{array}\right)$ \\
\hline \multicolumn{5}{|l|}{ IMD quintiles } \\
\hline 1 & 3,911 & $202(5.2)$ & $164(4.2)$ & \\
\hline 2 & 3,168 & $181(5.7)$ & 157 (5) & $1.18(0.94 \quad 1.48)$ \\
\hline 3 & 2,604 & $162(6.2)$ & $143(5.5)$ & $1.31\left(\begin{array}{lll}1.04 & 1.65\end{array}\right)$ \\
\hline 4 & 2,406 & $139(5.8)$ & $122(5.1)$ & $1.21\left(\begin{array}{lll}0.95 & 1.53)\end{array}\right)$ \\
\hline 5 & 1,917 & $128(6.7)$ & $110(5.7)$ & $1.37\left(\begin{array}{ll}1.07 & 1.76\end{array}\right)$ \\
\hline Missing & 28 & $2(7.1)$ & 1 (3.6) & \\
\hline
\end{tabular}


medRxiv preprint doi: https://doi.org/10.1101/2022.01.10.22268896; this version posted January 10, 2022. The copyright holder for this preprint (which was not certified by peer review) is the author/funder, who has granted medRxiv a license to display the preprint in All rights reserved. perpetuity.

\section{References}

1. WHO. WHO Coronavirus (COVID-19) Dashboard. WHO Coronavirus (COVID19) Dashboard With Vaccination Data [Internet]. Who. 2021. p. 1-5. Available from: https://covid19.who.int/

2. Tillett RL, Sevinsky JR, Hartley PD, Kerwin H, Crawford N, Gorzalski A, et al. Genomic evidence for reinfection with SARS-CoV-2: a case study. Lancet Infect Dis. 2021 Jan;21(1):52-8.

3. Impact of COVID-19 on childhood vaccination counts to week 9 in 2021, and vaccine coverage to January 2021 in England: interim analyses [Internet]. [cited 2021 Mar 29]. Available from:

https://www.gov.uk/government/publications/covid-19-impact-on-vaccinationprogrammes

4. Zhang K, Lau JY-N, Yang L, Ma Z-G. SARS-CoV-2 reinfection in two patients who have recovered from COVID-19. Precis Clin Med. 2020 Dec;3(4):292-3.

5. Nachmias V, Fusman R, Mann S, Koren G. The first case of documented Covid-19 reinfection in Israel. IDCases. 2020 Jan;22.

6. Tomassini S, Kotecha D, Bird PW, Folwell A, Biju S, Tang JW. Setting the criteria for SARS-CoV-2 reinfection - six possible cases. Vol. 82, Journal of Infection. W.B. Saunders Ltd; 2021. p. 282-327.

7. UKHSA. National flu and COVID-19 surveillance reports: 2021 to 2022 season - GOV.UK [Internet]. 2021 [cited 2021 Nov 18]. Available from: https://www.gov.uk/government/statistics/national-flu-and-covid-19surveillance-reports-2021-to-2022-season

8. Hall VJ, Foulkes S, Charlett A, Atti A, Monk EJM, Simmons R, et al. SARSCoV-2 infection rates of antibody-positive compared with antibody-negative health-care workers in England: a large, multicentre, prospective cohort study (SIREN). Lancet. 2021 Apr;397(10283):1459-69.

9. Hansen $\mathrm{CH}$, Michlmayr D, Gubbels SM, Mølbak K, Ethelberg S. Assessment of protection against reinfection with SARS-CoV-2 among 4 million PCR-tested individuals in Denmark in 2020: a population-level observational study. Lancet. 2021 Mar;397(10280):1204-12.

10. Abu-Raddad LJ, Chemaitelly H, Coyle P, Malek JA, Ahmed AA, Mohamoud YA, et al. SARS-CoV-2 reinfection in a cohort of 43,000 antibody-positive individuals followed for up to 35 weeks. medRxiv Prepr Serv Heal Sci. 2021 Feb;2021.01.15.21249731.

11. Sheehan MM, Reddy AJ, Rothberg MB. Reinfection Rates Among Patients Who Previously Tested Positive for Coronavirus Disease 2019: A Retrospective Cohort Study. Clin Infect Dis. 2021 Mar;

12. Brouqui $P$, Colson P, Melenotte C, Houhamdi L, Bedotto M, Devaux C, et al. COVID-19 re-infection. Eur J Clin Invest. 2021 Mar;51(5):e13537.

13. Volz E, Mishra S, Chand M, Barrett JC, Johnson R, Hopkins S, et al.

Transmission of SARS-CoV-2 Lineage B.1.1.7 in England: Insights from linking 
medRxiv preprint doi: https://doi.org/10.1101/2022.01.10.22268896; this version posted January 10, 2022. The copyright holder for this preprint (which was not certified by peer review) is the author/funder, who has granted medRxiv a license to display the preprint in

perpetuity.
reuse allowed without permission.

epidemiological and genetic data. medRxiv [Internet].

$2021 ; 2020.12 .30 .20249034$. Available from:

https://www.medrxiv.org/content/10.1101/2020.12.30.20249034v2\%0Ahttps://

www.medrxiv.org/content/10.1101/2020.12.30.20249034v2.abstract

14. Tegally H, Wilkinson E, Giovanetti M, Iranzadeh A, Fonseca V, Giandhari J, et al. Emergence and rapid spread of a new severe acute respiratory syndromerelated coronavirus 2 (SARS-CoV-2) lineage with multiple spike mutations in South Africa. medRxiv : the preprint server for health sciences. medRxiv; 2020.

15. Faria NR, Claro IM, Candido D, Franco LAM, Andrade PS, Thais M, et al. Genomic characterisation of an emergent SARS-CoV-2 lineage in Manaus: preliminary findings. VirologicalOrg [Internet]. 2021;1-9. Available from: https://virological.org/t/genomic-characterisation-of-an-emergent-sars-cov-2lineage-in-manaus-preliminary-findings/586

16. [ECDC] European Centre for Disease Prevention and Control. Threat assessment brief: emergence of SARS-CoV-2 B.1.617 variants in India and situation in the EU/EEA [Internet]. https://www.ecdc.europa.eu/en/publicationsdata/threat-assessment-emergence-sars-cov-2-b1617-variant. 2021 [cited 2021 Nov 18]. Available from: https://www.ecdc.europa.eu/en/publicationsdata/threat-assessment-emergence-sars-cov-2-b1617-variants

17. World Health Organization. Update on Omicron [Internet]. [cited 2021 Dec 20]. Available from: https://www.who.int/news/item/28-11-2021-update-on-omicron

18. Dhar MS, Marwal R, Radhakrishnan VS, Ponnusamy K, Jolly B, Bhoyar RC, et al. Genomic characterization and epidemiology of an emerging SARS CoV-2 variant in Delhi, India. Science (80-) [Internet]. 2021 Aug 20 [cited 2021 Nov 18];eabj9932. Available from:

https://www.medrxiv.org/content/10.1101/2021.06.02.21258076v3

19. Gu H, Chen Q, Yang G, He L, Fan H, Deng YQ, et al. Adaptation of SARSCoV-2 in BALB/c mice for testing vaccine efficacy. Science (80- ). 2020;369(6511):1603-7.

20. Cherian S, Potdar V, Jadhav S, Yadav P, Gupta N, Das M, et al. Sars-cov-2 spike mutations, 1452r, t478k, e484q and p681r, in the second wave of covid19 in Maharashtra, India. Microorganisms [Internet]. 2021 Jul 1 [cited 2021 Nov 18];9(7). Available from: /pmc/articles/PMC8307577/

21. Twohig KA, Nyberg T, Zaidi A, Thelwall S, Sinnathamby MA, Aliabadi S, et al. Hospital admission and emergency care attendance risk for SARS-CoV-2 delta (B.1.617.2) compared with alpha (B.1.1.7) variants of concern: a cohort study. Lancet Infect Dis [Internet]. 2021 Aug [cited 2021 Nov 18]; Available from: https://pubmed.ncbi.nlm.nih.gov/34461056/

22. Wang Z, Schmidt F, Weisblum Y, Muecksch F, Barnes CO, Finkin S, et al. mRNA vaccine-elicited antibodies to SARS-CoV-2 and circulating variants. Nature. 2021;592(7855):616-22.

23. Voysey M, Clemens SACSC, Madhi SSA, AI. E, Weckx LY, Folegatti PM, et al. Safety and efficacy of the ChAdOx1 nCoV-19 vaccine (AZD1222) against

SARS-CoV-2: an interim analysis of four randomised controlled trials in Brazil, 
medRxiv preprint doi: https://doi.org/10.1101/2022.01.10.22268896; this version posted January 10, 2022. The copyright holder for this preprint (which was not certified by peer review) is the author/funder, who has granted medRxiv a license to display the preprint in All rights reserved. No reuse allowed without permission.

South Africa, and the UK. Lancet. 2020 Jan;397(10269):99-111.

24. Fontanet A, Autran B, Lina B, Kieny MP, Karim SSA, Sridhar D. SARS-CoV-2 variants and ending the COVID-19 pandemic. Vol. 397, The Lancet. Elsevier Ltd; 2021. p. 952-4.

25. Wibmer CK, Ayres F, Hermanus T, Madzivhandila M, Kgagudi P, Oosthuysen B, et al. SARS-CoV-2 501Y.V2 escapes neutralization by South African COVID-19 donor plasma. Nat Med. 2021 Mar;27(4):622-5.

26. UKHSA. SARS-CoV-2 variants of concern and variants under investigation in England [Internet]. Vol. Technical briefing .... 2021 [cited 2021 Dec 20]. Available from: https://assets.publishing.service.gov.uk/government/uploads/system/uploads/a ttachment_data/file/1042367/technical_briefing-31-10-december-2021.pdf

27. Pulliam JRC, Van Schalkwyk C, Govender N, Von Gottberg A, Cohen C, Groome MJ, et al. Increased risk of SARS-CoV-2 reinfection associated with emergence of the Omicron variant in South Africa. [cited 2021 Dec 20]; Available from: https://doi.org/10.1101/2021.11.11.21266068

28. Wei J, Stoesser N, Matthews PC, Ayoubkhani D, Studley R, Bell I, et al. Antibody responses to SARS-CoV-2 vaccines in 45,965 adults from the general population of the United Kingdom. Nat Microbiol 202169 [Internet]. 2021 Jul 21 [cited 2021 Dec 13];6(9):1140-9. Available from: https://www.nature.com/articles/s41564-021-00947-3

29. Sources of COVID-19 surveillance systems - GOV.UK [Internet]. [cited 2021 Dec 13]. Available from: https://www.gov.uk/government/publications/nationalcovid-19-surveillance-reports/sources-of-covid-19-systems

30. Demographics - NHS Digital [Internet]. [cited 2021 Dec 13]. Available from: https://digital.nhs.uk/services/demographics

31. Public Health England. Understanding cycle threshold (Ct) in SARS-CoV-2 RT-PCR A guide for health protection teams [Internet]. [cited 2021 Dec 13]. Available from:

https://assets.publishing.service.gov.uk/government/uploads/system/uploads/a ttachment_data/file/926410/Understanding_Cycle_Threshold_Ct_in_SARSCoV-2_RT-PCR_.pdf

32. Centers for disease control and prevention. Investigative criteria for suspected cases of SARS-CoV-2 reinfection (ICR). Centers Dis Control Prev [Internet]. 2020 [cited 2021 Nov 18];1-3. Available from:

https://www.cdc.gov/coronavirus/2019-ncov/php/invest-criteria.html

33. Public Health England. SARS-CoV-2 variants of concern and variants under investigation in England. Technical briefing 14 [Internet]. [cited 2021 Dec 13]. Available from:

https://assets.publishing.service.gov.uk/government/uploads/system/uploads/a ttachment_data/file/991343/Variants_of_Concern_VOC_Technical_Briefing_14 .pdf

34. Public Health England. SARS-CoV-2 variants of concern and variants under investigation. Technical briefing 19 [Internet]. 2021 [cited 2021 Dec 13]. 
medRxiv preprint doi: https://doi.org/10.1101/2022.01.10.22268896; this version posted January $10,2022$. The copyright holder for this

preprint (which was not certified by peer review) is the author/funder, who has granted medRxiv a license to display the preprint in All rights reserved. No reuse allowed without permission.

Available from:

https://assets.publishing.service.gov.uk/government/uploads/system/uploads/a ttachment_data/file/1005517/Technical_Briefing_19.pdf

35. Redd AD, Nardin A, Kared H, Bloch EM, Pekosz A, Laeyendecker O, et al. CD8+ T cell responses in COVID-19 convalescent individuals target conserved epitopes from multiple prominent SARS-CoV-2 circulating variants. medRxiv [Internet]. 2021 Jul 1 [cited 2021 Dec 13];8(7). Available from: /pmc/articles/PMC7885937/

36. Appelman B, van der Straten K, Lavell AHA, Schinkel M, Slim MA, Poniman M, et al. Time since SARS-CoV-2 infection and humoral immune response following BNT162b2 mRNA vaccination. EBioMedicine [Internet]. 2021 Oct 1 [cited 2021 Nov 18];72. Available from: https://pubmed.ncbi.nlm.nih.gov/34571363/

37. Schmidt F, Weisblum Y, Rutkowska M, Poston D, Da Silva J, Zhang F, et al. High genetic barrier to SARS-CoV-2 polyclonal neutralizing antibody escape. Nature [Internet]. 2021 Sep 20 [cited 2021 Nov 18];1-5. Available from: https://www.nature.com/articles/s41586-021-04005-0

38. Prendecki M, Clarke C, Brown J, Cox A, Gleeson S, Guckian M, et al. Effect of previous SARS-CoV-2 infection on humoral and T-cell responses to singledose BNT162b2 vaccine. Lancet. $2021 \mathrm{Feb} ; 0(0)$.

39. Manisty C, Otter AD, Treibel TA, McKnight Á, Altmann DM, Brooks T, et al. Antibody response to first BNT162b2 dose in previously SARS-CoV-2-infected individuals. Vol. 397, The Lancet. Elsevier; 2021. p. 1057-8.

40. Andrews N, Tessier E, Stowe J, Gower C, Kirsebom F, Simmons R, et al. Vaccine effectiveness and duration of protection of Comirnaty, Vaxzevria and Spikevax against mild and severe COVID-19 in the UK. medRxiv Prepr Serv Heal Sci [Internet]. 2021 Oct 6 [cited 2021 Nov 18];2021.09.15.21263583. Available from:

https://www.medrxiv.org/content/10.1101/2021.09.15.21263583v2 